This is an Accepted Manuscript of an article published by Taylor \& Francis Group in Marriage \& Family Review. The final publication is available via https://doi.org/10.1080/01494929.2022.2083283

\title{
Reasons to postpone childbearing during fertility decline in Finland
}

Kateryna Savelieva ${ }^{1,2}$, Markus Jokela ${ }^{2}$, Anna Rotkirch $^{3}$

${ }^{1}$ Helsinki Collegium for Advanced Studies, University of Helsinki, Helsinki, Finland

${ }^{2}$ Department of Psychology and Logopedics, Faculty of Medicine, University of Helsinki, Helsinki, Finland

${ }^{3}$ Population Research Institute, Väestöliitto, Helsinki, Finland

Corresponding author: Kateryna Savelieva, Helsinki Collegium for Advanced Studies, University of Helsinki, P.O. Box 4 (Fabianinkatu 24), 00014 University of Helsinki, Finland. E-mail: kateryna.savelieva@helsinki.fi, tel. +358504075216.

Acknowledgements. The study is part of NetResilience consortium (345183) funded by the Strategic Research Council at the Academy of Finland, 345184 (AR and KS) and 345186 (MJ). KS was supported by the Helsinki Collegium for Advanced Studies and the Finnish Cultural Foundation under grant 00200993. Data collection was supported by the Alli Paasikivi Foundation.

Conflict of interest: The authors declare no conflicts of interest. 


\title{
Reasons to postpone childbearing during fertility decline in Finland
}

\author{
We examined self-reported reasons to postpone childbearing during fertility decline in \\ Finland in 2010s and their associations with socio-demographic factors, as well as \\ social media use and work-related attitudes. Using representative survey data from \\ Finnish Family Barometers, the sample comprised participants aged 20-44 who did not \\ plan having (more) children soon. Based on exploratory factor analysis, reasons to \\ postpone childbearing were grouped into uncertain life situation, lifestyle preferences, \\ and completed fertility. Regression analysis results indicate that more stable life \\ situation, infrequent social media use, and lower work-orientation were related to lower \\ uncertainty, whereas being a woman, having no children, frequent social media use, \\ and higher work-orientation were associated with increased lifestyle preferences. \\ Uncertain life situation and lifestyle preferences influence childbearing decisions \\ independently of socio-demographic characteristics.
}

Keywords: fertility; fertility intentions; postponement of childbearing; social media use; work-related attitudes; uncertainty; lifestyle preferences.

\section{Introduction}

Since 2010, there has been a steep decline in the total fertility rates (TFR) in several European countries, including the Nordic countries. Finland has experienced a particularly pronounced decline, with TFR falling from 1.87 in 2010 to 1.35 children per woman in 2019 (Statistics Finland, 2020). Fertility has been declining among Finnish women of all age groups and different parities, but the decline of first-order births, especially among women under 30 years of age, contributed the most, around $75 \%$ of the whole decline (Hellstrand et al., 2020). Alongside with TFR, the tempo-adjusted TFR has decreased, suggesting that women not only postpone, but also reduce their lifetime number of children (Hellstrand et al., 2020). While the reasons for this situation are hotly debated, no single explanation has been identified, suggesting a larger cultural change (Hiilamo, 2020; Rotkirch, 2020). Here, we 
provide the first systematic examination of the self-reported reasons with which young adults explain their decisions to postpone or not to have (more) children in contemporary Finland.

Previous research has identified several central reasons for childbearing postponement including effective contraception, increased women's education and labor force participation, changes in partnerships, housing and economic uncertainty, gender inequity, and changes in values and norms regarding parenthood (for a review, see Mills et al., 2011). Both quantitative data and in-depth interviews studies indicate that especially having a permanent job and secure income are currently a crucial prerequisite for having children in high-income societies: people tend to postpone both the birth of the first child and of the subsequent children when they are uncertain about their economic and material security (Brinton et al., 2018; Goldstein et al., 2013; Lebano \& Jamieson, 2020). A major reasons to postpone the transition to parenthood is the idea of "taking time" to enjoy the lifestyle of young adulthood, as well as the cultural norms of "intensive parenting" and "total motherhood" through heavy investment in children, which can be challenging for especially women's career development (Lebano \& Jamieson, 2020). Perceived negative sides of parenthood may lead to voluntary childlessness or a so-called 'childfree lifestyle', the prevalence of which has more than doubled in Finland from around 5\% at the beginning of the century to around $12 \%$ in the 2010s, according to the Family Barometer surveys conducted by the Population Research Institute in Finland (Rotkirch et al., 2017). The vast majority of young adults do wish to have a child, although they can be hesitant and ambivalent about the timing of childbearing in the life course: for instance, a focus group study showed that parenthood was largely perceived as desirable, yet highly demanding and limiting (Rotkirch et al. 2017, Rotkirch 2020). Finally, union dissolution and relationship problems may also be among the leading reasons to postpone childbearing, given that both marriage rates and proportions of young adults in 
stable cohabitation or marriages have decreased in Finland recently (Jalovaara \& Fasang, 2017; Saarela \& Skirbekk, 2020).

The reasons for postponement of childbearing in the Nordic countries have been understudied, partly due to the lack of data on fertility ideals and intentions. Studies considering childbearing during the 2010s have often focused on Southern Europe, the economic and social context of which differs from the situation in the Nordic countries (among the notable exceptions are some studies with qualitative data, including Bergnéhr \& Bernhardt, 2013 and Brinton et al. 2018). The Nordic countries are known for their family friendly policies, maternal and child well-being, women's labor market attachment, and gender equity - factors which previously correlated with higher total fertility rates in wealthy countries, or at least with a more moderate decline of completed fertility (Frejka et al., 2018). However, at present we know little about the reasons shaping the childbearing decisions of young adults in the Nordic countries. Furthermore, previous studies examining reasons to postpone childbearing have mainly focused on childless people, whereas little is known about parents' childbearing decisions regarding postponement of the birth of second or subsequent children. The present study examined self-reported reasons, with which both childless people and parents explain their decision to postpone or renounce childbearing during fertility decline in the Nordic countries in the 2010s, with data from Finland. We also investigated which groups of people are more likely to report which reasons, as well as how recent sociocultural changes, i.e., widespread use of social media and work-related attitudes, are related to their childbearing decisions.

\section{Theoretical background}

Postponement of childbearing has been linked to several economic, sociocultural, gendered, and economic explanations. Previous research showed that childbearing in high- 
income societies is usually postponed during times of economic uncertainty and accelerated during economic growth (Sobotka et al., 2011). However, although the fertility decline in the 2010s in Finland coincided with the Great Recession in 2008, recession indicators do not fully explain the decreasing fertility rates in Finland or the other Nordic countries (Comolli et al., 2020; Hiilamo, 2020).

A broader and more cultural interpretation is offered through the second demographic transition theory (SDT) (Lesthaeghe, 2014). The SDT highlights the role of ideational factors and value changes in family formation, including childbearing postponement, since individual choices have largely replaced strict marital and social norms as determinants of childbearing in developed countries (Lesthaeghe, 2014, 2010). Both the prolonged time spent in education and career building and the spread of post-materialist values such as the need for self-actualization, self-development, and consumption/leisure aspirations are related to postponement of childbearing and, consequently, to lower fertility rates (Lesthaeghe, 2014). At the same time, increased gender equality and greater emancipation of young adults has been suggested to support moderately high fertility levels (Lesthaeghe, 2010), as was indeed the case in the Nordic countries before the fertility decline of the last decade, at least on the macro-level (but not necessarily on the individual and household level, see Miettinen, Basten \& Rotkirch, 2011).

As a complement to the SDT, preference theory (Hakim, 2003) suggests that the heterogeneity of women's preferences and priorities regarding family and employment relate to the different lifestyles they adopt. Hakim (2003) defines three lifestyles - adaptive, workcentered, and home-centered - which are assumed to shape women's childbearing, employment patterns, and their responsiveness to family policies. For example, workcentered women are more likely to have children later in life, have a lower number of children, or to remain childless compared to adaptive or home-centered women (Hakim, 
2003). However, the Nordic countries are known as examples of promoting the reconciliation of employment and family life, and nothing suggests that the structural demands of education or careers, or women's general preferences would have altered significantly in the $2010 \mathrm{~s}$ compared to the situation ten years earlier. Hence neither economic explanations, SDT or preference theory seem to fully grasp changing childbearing intentions and behaviour in the Nordic countries.

Therefore, family demographers have stressed the need for new explanations to better capture recent changes (Comolli et al., 2020). For instance, expectations and perceptions of the future, which do not necessarily directly reflect actual economic situation or current circumstances, have been emphasized as playing an important and previously underestimated role in fertility decisions (Vignoli et al., 2020a). Within the Narrative Framework, people act according to or despite uncertainty, based on their own perceptions of their life prospects and their "narratives of the future", and such narratives are shaped by several social and cultural factors (Vignoli et al., 2020a). It has been also suggested that uncertainty in young adult's life has increased due to escalated globalization and the rise of new information channels (Vignoli et al., 2020b). Overall, broader perceived and multidimensional uncertainty might play a greater role in people's fertility decisions than previously assumed economic uncertainty (see also Aassve et al., 2021).

\section{Changes in lifestyle and childbearing decisions}

Among the changes in lifestyle occurring in 2010s that may have influenced current attitudes to childbearing and parenthood is the rapid spread of social media, which quickly became a widespread and ingrained part of everyday life. In Finland, over $90 \%$ of young adults own a smart phone and over $80 \%$ of Finns aged 20-44 say they are on social media several times a day or constantly (Tammisalo et al., 2020). Another major cultural shift is the 
global spread of the norm of dual breadwinners and of work-related attitudes ('workism') (DeRose and Stone, 2021; Hiilamo, 2020; Thompson, 2019). Both the time spent on social media and career expectations can promote a lifestyle, in which life goals other than childbearing are prioritized, and as a result of which childbearing is postponed or renounced, as outlined below.

First, time spent with social media may be associated with childbearing decisions. A study by Guldi and Herbst (2017) has shown using US data that increased broadband access is related to the decline of teen birth rate in 1999-2007. Studies that examined the associations between television and reproductive behavior suggest that increased exposure to television in developing countries was related to lower desired and actual number of children (Westoff and Koffman, 2011), as well as to decreased sexual activity (Lucas and Wilson, 2019). For Finland, results by Tanskanen (2018) using register data suggest that increased social media use may be associated with declining fertility during 2012-2017.

The basic assumption behind the hypothesis that screen time and social media affects childbearing is time displacement, so that time spent with screens may mean time lost from other activities. Time displacement is currently contributing to lower relationship satisfaction (Tammisalo \& Rotkirch, forthcoming), which in turn is likely to affect childbearing intentions and outcomes. In addition to time displacement, life online may also directly affect childbearing intentions, by exposing viewers to lifestyles that often compete with traditional attitudes toward marriage and family (Hiilamo, 2020; Rotkirch et al., 2017). Having a child itself is in some sociodemographic groups framed as a "non-modern" activity, at odds with a modern fashionable lifestyle (Bergnéhr and Bernhardt, 2013). Furthermore, social media may reduce contacts between childless individuals and parents with small children (Hiilamo, 2020; Rotkirch et al., 2017). Finally, social media use may also foster stress and high reactivity, feeding into a perception of instability and uncertainty and shaping people's 
narratives about how parenthood would affect their own future prospects in life (Vignoli et al., 2020b). In sum, active social media users may thus be more likely to consider lifestyle as a reason to postpone childbearing or not to have (more) children at all, but this question has not previously been investigated with representative survey data.

Second, work-related attitudes and expectations may also contribute to the recent fertility decline (DeRose and Stone, 2021). For instance, Brinton et al., 2018 described how women in highly gender-equal countries such as Sweden tend to restrain their fertility plans because of strong social norms, according to which both men and women should be engaged in paid employment and have an established career. Difficulties in obtaining a permanent job position may make women postpone childbearing or revise their fertility intentions in general. According to the preference theory (Hakim, 2003), work-centered women are more likely to postpone or renounce childbearing, yet it remains unclear whether higher workorientation is related to concerns regarding difficulties to combine work and family life or rather to a certain lifestyle which women want to follow in contemporary Nordic countries. It is also not clear whether work-related attitudes are differently related to childbearing decisions among childless people and parents.

Finally, partnership status and parental status, as well as various socio-demographic factors can be assumed to shape childbearing intentions and the reasons provided for them. For example, more highly educated women face higher opportunity costs when deciding to have children compared to lower educated women, which, in turn, translate to higher likelihood of childbearing postponement (Liefbroer, 2005) (for recent evidence from Finland for the wage penalty for mothers in different socioeconomic groups, see Berg, Lawson \& Rotkirch (2020)). In Finland, both men and women of lower educational status have had the most severe decline in fertility rates, as measured in both lower total period fertility (Statistics Finland 2020) and completed fertility (Jalovaara et al. 2018). It is possible that people with 
lower SES are more likely to postpone or renounce childbearing in the Nordic countries, or prefer lower family sizes, due to higher economic constraints, lack of partners, or other reasons. However, no previous study has investigated whether the reasons people report for postponing childbearing differ between lower- and higher-SES men and women.

\section{Present study}

This study examined the reasons Finns of reproductive age report to explain their decision to postpone or not to have (more) children during the recent fertility decline in the 2010s in Finland. Using representative survey data, we first identified the factors of reasons provided to postpone or not to have (more) children based on the exploratory factor analysis. We then examined how these identified factors are related to various socio-demographic characteristics, social media use, and work-related attitudes.

\section{Methods}

\section{Sample}

We used cross-sectional data from the two recent Family Barometer surveys (i.e., 2015 and 2018), conducted by Väestöliitto, the Finnish Family Federation to study various topics related to family life and childbearing in Finland. The surveys were conducted in Spring 2015 (sample $\mathrm{n}=3180)$ and Spring 2018 (sample $\mathrm{n}=2638)$. Both surveys were conducted as online surveys by KANTAR TNS Gallup Oyj using their panel of participants consisting of approximately 50000 households representing the Finnish population (excluding the Åland islands), among whom participants were recruited during the time of the survey. The sample size for the online surveys was predetermined, and the data collection was finished once the sample size was reached. Participants were compared to the whole population in Finland, and the data were weighted if discrepancies were discovered. 
Reasons to postpone or renounce childbearing, as well as the other variables of interest were asked in both surveys, therefore we combined the data to use all the available information for our analyses (except for social media use, included only in 2018 and analyzed only for that year). The total sample comprised 5818 participants $(61.5 \%$ were female, $48.2 \%$ childless) aged 20-59. We excluded survey participants with low probability of childbearing due to age (45 years or older), resulting in 3756 participants. Both childless survey participants and parents were first asked whether they plan to have (more) children, and those participants who postponed to have a(nother) child (i.e., plan to have children at some point in the future, $n=1268,36.6 \%$ ), did not plan to have (more) children $(n=1734,50 \%)$, or could not say whether they plan to have (more) children $(n=466,13.4 \%)$, were asked to select suitable reasons for this decision from a predetermined list. Thus, the final analytical sample comprised 3468 participants.

\section{Measures}

Reasons to postpone or not to have (more) children

The list of 27 reasons that affect the decision to postpone or not to have (more) children is shown in Supplementary Table 1. The predetermined set of responses was initially adapted from the Fertility and Family Surveys but have been shortened and adapted to the Finnish Family Barometers, allowing for adjustments over time. The phrasing of these reasons was the same in both survey years, although the wording of the question and response options differ. In the 2015 survey, the participants were asked to indicate how important is each of the following reasons for their decision to postpone or not to have (more) children (with the response scale being $1=$ very important, $2=$ somewhat important, $3=$ not very important, $4=$ not important at all, and $5=$ can't say or doesn't apply to me). In the 2018 survey, the participants were asked to what extent the following reasons affect their decision to postpone or not to have (more) children (response scale: $1=$ affects a lot, $2=$ has some 
effect, 3 = has little effect, 4 = does not affect at all, 5 = can't say or doesn't apply to me).

Given that the content of the questions was similar and the phrasing of reasons was the same in both surveys, we combined the data from two surveys. The response scale for the items was recoded in the following way: 0 indicates 'can't say or doesn't apply to me' and 4 indicates 'affects a lot' or 'very important'. Supplementary Table 2 shows the distributions of responses, and Supplementary Table 3 provides the comparison of items' means across two survey years.

\section{Social media use}

Social media use was self-reported in the 2018 survey using the question "How often do you use social media at home?" and coded as a categorical variable $(1=$ never/rare/sometimes, $2=$ often, $3=$ all the time/very often). Work-related attitudes

Work-related attitudes were self-reported using the question "Most of my life goals are related to work" and coded as a continuous variable $(1=$ totally disagree, $2=$ somewhat disagree, $2.5=$ neither agree nor disagree, $3=$ somewhat agree, and $4=$ totally agree).

\section{Socio-demographic characteristics}

The socio-demographic characteristics include the following variables: age (used as a continuous variable $)$, gender $(0=$ male, $1=$ female $)$, education $(1=$ basic, $2=$ secondary, $3=$ lower tertiary, $4=$ upper tertiary $)$, employment $(1=$ employed, $2=$ unemployed, $3=$ not working, that is being a student/on maternity or paternity leave), respondent's annual gross income (used as a continuous variable and coded as $1=$ less than 10000 euros, $2=10000$ 20000 euros, 3 = 20001-30000 euros, 4 = 30001-40000 euros, $5=40001-50000$ euros, $6=$ over 50000 euros $)$, partnership status $(0=$ single, widowed, divorced, or separated, $1=$ cohabiting, 2 = married or being in a registered partnership), number of children (coded as 0 , $1,2,3+)$, house ownership ( $0=$ not owning a house, $1=$ being a house owner $)$, and region of 
residence (1= Metropolitan area, $2=$ Uusimaa and Southern Finland, $3=$ Western Finland, 4 $=$ Northern and Eastern Finland).

\section{Statistical analysis}

\section{Exploratory factor analysis}

We conducted an exploratory factor analysis (EFA) to examine the factor structure of 27 items which explain the decision to postpone or not to have (more) children. Sampling adequacy for conducting a factor analysis was tested using the Kaiser-Meyer-Olkin Measure of Sampling Adequacy (KMO) and the Bartlett's test of sphericity. KMO ranged from 0 to 1 and indicates the proportion of variance in variables that might be explained by latent factors; the Bartlett's test of sphericity tests the hypothesis that the correlation matrix has an identity matrix. We used the EFA with a principal factor method and applied the promax (oblique) rotation using the Kaiser normalization allowing the factors to be correlated. We then computed the summary score for each factor by adding together the items loading high on the factor of interest.

\section{Missing data analysis}

The complete sample comprised 3468 participants aged 20-44 years who reported reasons to postpone or renounce childbearing. Of those, 541 participants (15.6\%) did not report their income, $29(0.8 \%)$ did not report education, and $197(5.7 \%)$ did not report their work-related attitudes. We conducted multiple imputation by chained equations (Van Buuren, 2018) to impute missing values for income, education, and work-related attitudes. All regression analyses were conducted using the pooled estimates of 20 imputed data sets. Regression analysis

First, we examined the associations between the socio-demographic characteristics (i.e., age, gender, partnership status, number of children, education, employment, income, house ownership, and region of residence) and identified dimensions of self-reported reasons 
to postpone or not to have (more) children in the total sample using negative binomial regression. We then examined the associations between social media use and work-related attitudes with the self-reported reasons to postpone or not to have (more) children after adjusting for the above-mentioned socio-demographic characteristics. Social media use and work-related attitudes were analyzed in separate models. All analyses were also adjusted for the survey year to avoid any potential differences between the two surveys related to the different wording of the response scales. We also repeated the above-mentioned analyses separately for childless people and parents, as well as for men and women.

All the analyses were conducted using sampling weights and performed in Stata 15 (StataCorp, 2017).

Supplementary analyses

As a sensitivity analysis, we repeated the exploratory factor analyses so that the response options “can't say or doesn't apply to me" were treated as missing values. We also repeated the EFA separately for people who decided to postpone having children and for those who decided not to have (more) children.

\section{Results}

\section{Descriptive statistics}

Table 1 shows the descriptive statistics of the analytical sample. The mean age of participants was 33.6 years $(S D=6.98), 63.5 \%$ were female, $31.5 \%$ were married and $26.5 \%$ cohabiting. More than half of the respondents were childless $(57.8 \%)$. Among parents, $45 \%$ had one child only, and $39 \%$ had two children.

\section{Exploratory factor analysis}

The sampling adequacy for conducting a factor analysis was good, with KMO = 0.899 and the Bartlett's test of sphericity being $p<0.001$. Using EFA with a principal factor 
method, three factors with eigenvalues higher than 1 were extracted (Supplementary Figure 1). In the unrotated solution, the first factor had eigenvalue of 7.2 and explained $58 \%$ of the shared variance, the second factor had eigenvalue of 2.3 and explained $18 \%$, and the third factor had eigenvalue of 1.9 and explained $15 \%$ of the shared variance. Factor 1 positively correlated with Factor $2(\mathrm{r}=.37)$ and Factor $3(\mathrm{r}=.31)$; Factor 2 positively correlated with Factor $3(r=.21)$. After the rotation, the variances of the factors were the following: 5.9 for Factor 1, 4.5 for Factor 2, and 4.0 for Factor 3. The rotated factor loadings for all items are shown in Table 2.

After examining the content of items loading high on these three factors $(>0.30)$, the factors were named as follows: Factor 1 - "Uncertain life situation", Factor 2 - "Lifestyle preferences", and Factor 3 - "Completed fertility". Since we were primarily interested in the reasons to postpone parenthood or having subsequent children, those who had completed their childbearing goals as reflected in the third factor were not used in the further analysis. Table 1 shows the median and interquartile range for uncertain life situation and lifestyle preferences factors that were further used in the regression analyses.

As a sensitivity analysis, we repeated the EFA when the responses “can't say or doesn't apply to me" were treated as missing values $(n=660)$. The factors' structure and loadings were similar to the whole sample and comprised three factors - "Uncertain life situation", "Lifestyle preferences", and "Completed fertility" (Supplementary Table 4). In the unrotated solution, the first factor had eigenvalue of 9.9 and explained $67 \%$ of the shared variance, the second factor had eigenvalue of 2.1 and explained $14 \%$, and the third factor had eigenvalue of 1.7 and explained $11 \%$ of the shared variance. After the rotation, the variances of the factors were the following: 8.7 for Factor 1, 5.8 for Factor 2, and 5.4 for Factor 3.

We additionally conducted the exploratory factor analysis separately among those participants who postpone childbearing (i.e., plan to have children at some point in the future, 
$\mathrm{n}=1268$ ) and those who renounce childbearing (i.e., did not plan to have (more) children, $\mathrm{n}$ =1734). Among those who postpone childbearing, the factors' structure and loadings were similar to the total sample and comprised three factors - Uncertain life situation, Lifestyle preferences, and Completed fertility (Supplementary Table 5). Among those who do not plan to have (more) children, an additional fourth factor could be identified, comprising three items ("I don't think I am suitable for parenting", "I don't like children", and "I'm still too young, or I do not feel mature enough") and was named as "Not ready for parenting".

(Supplementary Table 6). Below, we focus on the factors loading in the overall sample. Self-reported reasons to postpone or not to have (more) children: associations with socio-

\section{demographic characteristics}

Table 3 shows the associations between the socio-demographic characteristics and the identified uncertain life situation factor and the lifestyle preferences factor in the total sample. Older age, higher income, and living in other parts of Finland than the metropolitan area were associated with lower likelihood of reporting reasons to postpone or not have (more) children which formed the uncertain life situation factor. In contrast, cohabiting or being married and having at least one child were associated with higher likelihood of reporting reasons related to the uncertain life situation factor. No associations were found between education, employment status, and house ownership with the reasons related to the uncertain life situation factor in the total sample. When we examined these associations separately among childless people and parents, living with a spouse through marriage or cohabitation was related to higher likelihood of belonging to the uncertain life situation factor among the childless, but not among parents. Childless women were also more likely to report reasons related to uncertain life situation compared to mothers (Supplementary Table 7).

Regarding the lifestyle preferences factor, few associations were detected between socio-demographic characteristics and reasons to postpone or not to have (more) children 
(Table 3). As can be expected, number of children was strongly associated with a lower likelihood of reporting reasons to postpone childbearing related to the lifestyle preferences factor. Women were more likely to report reasons related to the lifestyle preferences factor. Cohabiting, but not being married, was also related to a higher likelihood of belonging to the lifestyle preferences factor in the total sample. Furthermore, among childless people, both cohabiting and being married were associated with a higher likelihood of reporting reasons related to the lifestyle preferences factor, whereas among parents being married was related to a lower likelihood of reporting reasons from the lifestyle preferences factor (Supplementary Table 7).

Lastly, we examined the results separately for men and women (Supplementary Table 8). Having at least one child was strongly associated with higher likelihood of reporting reasons related to uncertain life situation factor for both genders. At the same time, having at least one child was related to lower likelihood of belonging to the lifestyle preferences factor both among men and women. Higher education was associated with higher likelihood of reporting reasons related both to the uncertain life situation factor and lifestyle preferences factor, but only among women. Higher income was related to lower likelihood of reporting the reasons related to the uncertain life situation factor only among men; whereas owning a house and living in other parts of Finland than the metropolitan area were related to lower likelihood of reporting reasons related to uncertain life situation factor only among women.

\section{Associations with social media use and work-related attitudes}

Dose-response associations were found between the frequency of social media use and the reasons to postpone or not to have (more) children related both to the uncertain life situation factor $(\mathrm{IRR}=1.03,95 \%$ CI $1.00,1.06$ for linear trend $)$ and the lifestyle preferences factor $(\mathrm{IRR}=1.04,95 \%$ CI 1.01, 1.06 for linear trend $)$ in the total sample. Compared to 
people who reported using social media less frequently, those who reported using it very often were more likely to report reasons related to both uncertain life situation factor and lifestyle preferences factor (Figure 1).

Likewise, dose-response associations were found between the work-related attitudes and the reasons to postpone or not to have (more) children related to both uncertain life situation factor $(\mathrm{IRR}=1.18,95 \%$ CI 1.14, 1.21 for linear trend $)$ and lifestyle preferences factor $(\mathrm{IRR}=1.12,95 \%$ CI 1.09, 1.15 for linear trend). People who were more work-oriented were more likely to report reasons related to both uncertain life situation factor and lifestyle preferences factor (Figure 1).

Interestingly, the frequency of social media use was associated with the reasons related to both uncertain life situation and lifestyle preferences factors only among childless people; whereas the associations with work-related attitudes were similar between childless and parents (Figure 2.A). Among men and women, the associations between social media use and work-related attitudes with the likelihood of being in the uncertain life situation factor and the lifestyle preferences factor were similar (Figure 2.B).

\section{Discussion}

Recent fertility decline in high-income countries with family-friendly policies and previously relatively high fertility rates is not well understood or grasped by prevailing theoretical frameworks, warranting a closer look on subjective reasons behind childbearing decisions. Using nationally representative survey data from contemporary Finland, this study examined the self-reported reasons with which adults of reproductive age explain their decision to postpone or not to have (more) children. Our exploratory factor analysis suggested three larger factors behind childbearing decisions: uncertain life situation, lifestyle preferences, and completed fertility. We found that people with a more stable life situation, little social media 
use, having at least one child, and lower work-orientation were less likely to state uncertain life situation as a reason for not having a(nother) child now; whereas being a woman, having no children, using social media extensively, and being more work-oriented were associated with the lifestyle preferences factor. Compared to women with lower education, women with higher education were more likely to report reasons which were related to both uncertain life situation and lifestyle preferences factors, whereas no such associations were found for men.

In our study, uncertain life situation emerged as the strongest factor behind the decision to postpone or not to have (more) children. The factor loaded with many dimensions from uncertainty, ranging from perceived financial situation and own or spouse's unfinished studies to size of apartment and challenges in combining wage work and child care. This is in line with recent research showing that not only objective factors related to uncertainty, such as unemployment or income, may influence fertility rates, but also perceived economic and financial uncertainty contributes to childbearing postponement in wealthy countries in the last decade (Brinton et al., 2018; Lebano \& Jamieson, 2020). For instance, in the Nordic countries, childbearing plans may be currently more affected by perceptions of insecurity related to welfare state provisions than to the direct employment situation or family policy legislation (Comolli et al., 2020). Our results are also in line with the theoretical approach suggested by the Narrative Framework (Vignoli et al., 2020a), which highlights the role of uncertainty and people's own narratives and expectations of the future, in addition to the actual economic situation. We contribute to this framework by documenting the multidimensional character of uncertainty: it can be related to more objective factors such as financial situation, work instability, and unfinished studies, but also to career aspirations, concerns regarding arrangement of childcare, and support from society. As could have been expected, people with a more stable life situation (e.g., men with higher income and women being a house owner) were less likely to say that various reasons related to uncertainty in life 
explained why they did not intend to have (more) children at the moment. However, women with higher education were more likely to state reasons related to uncertain life situation factor compared to women with lower education. This result may be interpreted through the lenses of preference theory (Hakim, 2003), because women with higher education have higher economic opportunity costs when deciding to have children compared to lower educated women (Berg et al., 2020).

The second main factor for postponing or renouncing childbearing was lifestyle preferences: adults who did not want to change their current lifestyle and preferred to do other things in life than childbearing. Being a woman, having no children, and having higher education were more common among those who said that lifestyle preferences made them not to have children at the moment. We also found that cohabiting (but unmarried) respondents were more likely to state reasons related to lifestyle preferences compared to those who were single. It could be that single people may primarily report not having a suitable partner as their main reason to postpone having children, even though they might additionally experience uncertain life situation or prefer to do other things in life than childbearing. The association between partnership status and reporting lifestyle preferences reasons was especially pronounced among childless people, for whom both cohabiting and being married was associated with higher likelihood of belonging to the lifestyle preferences factor. On the other hand, for people who had at least one child, cohabiting was not related to lifestyle preferences reasons, whereas being married was associated with lower likelihood of reporting reasons related to lifestyle preferences factor. This result supports a recent study with register data from Finland, showing a more rapid decline in first births among cohabiting couples than among married couples (Hellstrand, Nisén, \& Myrskylä, 2021), and suggests that reluctance to change current lifestyle and desire to do other things in life than childbearing partly explains the decline in fertility among couples. 
As stressed by second demographic transition theory (Lesthaeghe, 2014), people might postpone or forgo having (more) children due to the need of self-actualization and selfdevelopment, as well as due to the leisure aspirations, given that more leisure-oriented women tend to delay their first births (Arránz Becker \& Lois, 2013). Our results are also consistent with a recent study from Southern European countries (Lebano \& Jamieson, 2020), showing that the idea of "taking time" is becoming one of the prevailing reasons to postpone childbearing. Among childless people, childfree ideals have risen among recent birth cohorts (e.g., people born in 1980s and 1990s; Savelieva et al., 2021), and an increasing number of young childless women postpone the birth of their first child (Hellstrand et al., 2020). It seems that the gradual normalization of a childfree lifestyle may further enhance the importance of lifestyle factors in decisions to postpone childbearing or remain childless (Mills et al., 2011). Additionally, especially young people appear to have ambivalent feelings about having children: although young adults believe that children make life more meaningful, they tend to postpone the transition to parenthood to be able to enjoy the childfree lifestyle and the possibility to do other things of interest (Bergnéhr \& Bernhardt, 2013, Rotkirch 2020). More research into the growth of childfree lifestyles and the factors contributing to it in different life situations is needed.

We also investigated how social media and work orientation are related to postponement of childbearing. As increasingly often suggested but not shown with survey data previously, recent changes in lifestyle - spread of social media use and increased work orientation - were indeed related to perceived obstacles to childbearing. In particular, people with higher work-related attitudes were more likely to report reasons to postpone or not to have (more) children related to both uncertain life situation and lifestyle preferences factors. These associations were similar between men and women, as well as between childless people and parents. Furthermore, people who reported using social media more frequently, 
compared to those who reported using it less often, were more likely to report reasons related to both uncertain life situation and lifestyle preferences factors. These associations were especially relevant for childless people, whereas the frequency of social media use was not associated with reasons related to uncertain life situation and lifestyle preferences factors among parents. No direction of associations can be inferred based on our cross-sectional data, and the mechanisms which could explain these associations merit further research. Nevertheless, it seems plausible that extensive social media use among childless people is related to both higher uncertainty about the future and acceptance of the lifestyle which is not compatible with childbearing, for example, by taking time to enjoy other things in life or higher leisure-orientation (Rotkirch et al., 2017; Vignoli et al., 2020b). Extensive social media use may also lower fertility intentions indirectly, by lowering relationship satisfaction, or adding to a sense of stress or anxiety (Tammisalo \& Rotkirch, forthcoming)

\section{Limitations}

Our study has some limitations. First, as mentioned above, due to the cross-sectional nature of the survey data no conclusions about the direction of associations can be made. Second, the phrasing of the questions and response scales for the self-reported reasons to postpone or not to have (more) children were slightly different between the questionnaires used in 2015 and 2018 surveys, but the content of the questions and response items was the same. Given that there were statistically significant mean differences in some items across the survey years, all regression analyses were adjusted for the survey year. Third, social media use was reported only in 2018 survey, hence all the analyses using social media use were conducted in a restricted sample. We also lack information about the specific content of social media used in our data, only information about the frequency of social media use. However, a recent review indicates that time spent on screens or more specifically on social media remains a valid measure for assessing their impact on everyday life wellbeing and 
behaviour (Tammisalo \& Rotkirch, forthcoming). Fourth, it should be noted that the factor structure of reasons with which people explain their childbearing decision was limited to the predetermined list of 27 reasons provided in the survey. It is possible that some factors could not manifest themselves as no suitable items were in the survey in the first place, or the results might differ if survey participants would have been asked to list their own reasons in addition to the predetermined list of 27 items. However, based on the findings from the 12 focus groups with altogether 50 young men and women aged 19-33 coming from different socioeconomic and regional background (see Rotkirch et al., 2017; Kielinen 2018), we believe the predetermined questions capture sentiments regarding childbearing well, with the possible exception for climate change-related reasons. Finally, although the sample was weighted to correspond to nationwide population characteristics in age, gender, residence, number of children, and educational level, it is possible that participants were selected on some other traits, for instance related to the theme of the survey, which could create biases that weighting cannot account for.

\section{Implications}

In terms of implications for practice, our findings suggest that policy makers should consider uncertainty (both objective and perceived), as well as lifestyle preferences when introducing measures to support family formation and new family policies. The recent guidelines for population policy in 2020s in Finland (Rotkirch, 2021) highlight the importance of taking into account people's aspirations towards childbearing within a human and sexual rights framework (see section 5.2 "Children - of course" in Rotkirch, 2021). Since our results indicate that work orientation and social media use may feed into perceptions of the costs and benefits of childbearing, promoting work-life balance and digital well-being may be beneficial not only from the perspective of individual health and well-being, but also in order to reduce the gap between ideal and achieved numbers of children in wealthy 
societies. As for the implications for research, this study examined people's reasons to postpone or not to have (more) children before the Covid-19 pandemic and Russia's invasion of Ukraine, so it would be important to investigate how they have changed during the times of escalating crises.

\section{Conclusion}

In conclusion, our findings from Finland show that reported reasons to postpone or not to have (more) children can be grouped into three factors: uncertain life situation, lifestyle preferences, and completed fertility. Among lifestyle and socio-demographic factors, social media use, work-related attitudes, and lower overall life stability increase the likelihood of reporting both uncertainty and lifestyle preferences as reasons for postponing or not having (more) children. 


\section{References}

Arránz Becker, O., \& Lois, D. (2013). Competing pleasures? The impact of leisure time use on the transition to parenthood. Journal of Family Issues, 34(5), 661-688. https://doi.org/10.1177/0192513X12437694

Aassve, A., Le Moglie, M., \& Mencarini, L. (2021). Trust and fertility in uncertain times. Population Studies, 75(1), 19-36. https://doi.org/10.1080/00324728.2020.1742927

Berg, V., Lawson, D. W., \& Rotkirch, A. (2020). Financial opportunity costs and deaths among close kin are independently associated with reproductive timing in a contemporary high-income society. Proceedings of the Royal Society B: Biological Sciences, 287(1919), 20192478. https://doi.org/10.1098/rspb.2019.2478

Bergnéhr, D., \& Bernhardt, E. (2013). The non-modern child? Ambivalence about parenthood among young adults. In A. L. Ellingsaeter, A.-M. Jensen, \& M. Lie (Eds.), The Social Meaning of Children and Fertility Change in Europe (pp. 102-119). https://doi.org/10.4324/9780203070635

Brinton, M. C., Bueno, X., Oláh, L., \& Hellum, M. (2018). Postindustrial fertility ideals, intentions, and gender inequality: A comparative qualitative analysis. Population and Development Review, 44(2), 281-309. https://doi.org/10.1111/padr.12128

Comolli, C. L., Neyer, G., Andersson, G., Dommermuth, L., Fallesen, P., Jalovaara, M., ... Lappegård, T. (2020). Beyond the economic gaze: Childbearing during and after recessions in the Nordic countries. European Journal of Population, 37, 473-520. https://doi.org/10.1007/s10680-020-09570-0

DeRose, L., \& Stone, L. (2021). More Work, Fewer Babies: What Does Workism Have to Do with Falling Fertility? Retrieved from https://ifstudies.org/ifsadmin/resources/reports/ifs-workismreport-final-031721.pdf

Frejka, T., Goldscheider, F., \& Lappegård, T. (2018). The two-part gender revolution, 
women's second shift and changing cohort fertility. Comparative Population Studies, 43, 99-130. https://doi.org/10.12765/CPoS-2018-09en

Goldstein, J., Karaman Örsal, D. D., Kreyenfeld, M., \& Jasilioniene, A. (2013). Fertility reactions to the "Great Recession" in Europe. Demographic Research, 29, 85-104. https://doi.org/10.4054/DemRes.2013.29.4

Guldi, M., \& Herbst, C. M. (2017). Offline effects of online connecting: The impact of broadband diffusion on teen fertility decisions. Journal of Population Economics, 30(1), 69-91. https://doi.org/10.1007/s00148-016-0605-0

Hakim, C. (2003). A new approach to explaining fertility patterns: Preference theory. Population and Development Review, 29(3), 349-374. https://doi.org/10.1111/j.17284457.2003.00349.x

Hellstrand, J., Nisén, J., \& Myrskylä, M. (2020). All-time low period fertility in Finland: Demographic drivers, tempo effects, and cohort implications. Population Studies, 1-15. https://doi.org/10.1080/00324728.2020.1750677

Hellstrand, J., Nisén, J., \& Myrskylä, M. (2021). Less partnering, less children, or both? Analysis of the drivers of first-birth decline in Finland since 2010? Max Plank Demographic Research Institute, Rostock, MPIDR Working Paper WP 2021-008. https://doi.org/10.4054/MPIDR-WP-2021-008

Hiilamo, P. H. (2020). Why fertility has been declining in Finland after the Global Recession? Finnish Yearbook of Population Research, 54, 29-51. https://doi.org/10.23979/fypr.85090

Jalovaara, M., \& Fasang, A. E. (2017). From never partnered to serial cohabitors: Union trajectories to childlessness. Demographic Research, 36, 1703-1720. https://doi.org/10.4054/DemRes.2017.36.55

Jalovaara, M., Neyer, G., Andersson, G., Dahlberg, J., Dommermuth, L., Fallesen, P., \& 
Lappegård, T. (2018). Education, gender, and cohort fertility in the Nordic countries. European Journal of Population, 35(3), 563-586. https://doi.org/10.1007/s10680-018$9492-2$

Kielinen, P. (2018). "Farmariauto ja kaksi lasta”: Suomalaisten korkeakoulutettujen nuorten aikuisten näkemyksiä lastenhankinnasta. ["Station wagon and two children”: The views of Finnish adults with higher education on childcare]. University of Oulu, Master's thesis

Lebano, A., \& Jamieson, L. (2020). Childbearing in Italy and Spain: Postponement narratives. Population and Development Review, 46(1), 121-144. https://doi.org/10.1111/padr.12313

Lesthaeghe, R. (2010). The unfolding story of the second demographic transition. Population and Development Review, 36(2), 211-251. https://doi.org/10.1111/j.17284457.2010.00328.x

Lesthaeghe, R. (2014). The second demographic transition: A concise overview of its development: Table 1. Proceedings of the National Academy of Sciences, 111(51), 18112-18115. https://doi.org/10.1073/pnas.1420441111

Liefbroer, A. C. (2005). The impact of perceived costs and rewards of childbearing on entry into parenthood: Evidence from a panel study. European Journal of Population, 21(4), 367-391. https://doi.org/10.1007/s10680-005-2610-y

Lucas, A. M., \& Wilson, N. L. (2019). Does television kill your sex life? Microeconometric evidence from 80 countries. The B.E. Journal of Economic Analysis \& Policy, 19(4). https://doi.org/10.1515/bejeap-2018-0361

Miettinen, A., Basten, S., \& Rotkirch, A. (2011). Gender equality and fertility intentions revisited. Demographic Research, 24, 469-496. https://doi.org/10.4054/DemRes.2011.24.20 
Mills, M., Rindfuss, R. R., McDonald, P., \& te Velde, E. (2011b). Why do people postpone parenthood? Reasons and social policy incentives. Human Reproduction Update, 17(6), 848-860. https://doi.org/10.1093/humupd/dmr026

Rotkirch, A. (2020). The wish for a child. Vienna Yearbook of Population Research, 18, 113. https://doi.org/10.1553/populationyearbook2020.deb05

Rotkirch, A. (2021). Syntyvyyden Toipuminen Ja Pitenevä Elinikä: Linjauksia 2020-Luvun Väestöpolitiikalle [Recovery of the Birth Rate and Longer Life Expectancy - Guidelines for Population Policy in the 2020s]. Publications of the Prime Minister's Office 2021:2; Helsinki, Finland. http://urn.fi/URN:ISBN:978-952-383-073-8.

Rotkirch, A., Tammisalo, K., Miettinen, A., \& Berg, V. (2017). Miksi vanhemmuutta lykätään? Nuorten aikuisten näkemyksiä lastensaannista [Why do young adults postpone parenthood? Young adults' views on having children]. Perhebarometri 2017. Väestöntutkimuslaitos E51. Helsinki: Väestöliitto.

Saarela, J., \& Skirbekk, V. (2020). Childlessness and union histories: Evidence from Finnish population register data. Journal of Biosocial Science, 52(1), 78-96.

https://doi.org/10.1017/S0021932019000257

Savelieva, K., Nitsche, N., Berg, V., Miettinen, A., Rotkirch, A., \& Jokela, M. (2021). Birth cohort changes in fertility ideals: evidence from repeated cross-sectional surveys in Finland. Max Plank Demographic Research Institute, Rostock, MPIDR Working Paper WP 2021-010. https://doi.org/10.4054/MPIDR-WP-2021-010

Sobotka, T., Skirbekk, V., \& Philipov, D. (2011). Economic recession and fertility in the developed world. Population and Development Review, 37(2), 267-306. https://doi.org/10.1111/j.1728-4457.2011.00411.x

StataCorp. (2017). Stata Statistical Software: Release 15. College Station, TX: StataCorp LLC. 
Statistics Finland. (2020). Official Statistics of Finland (OSF): Births [e-publication].

ISSN=1798-2413. Helsinki: Statistics Finland [referred: 7.8.2020]. Access method: http://www.stat.fi/til/synt/index_en.html.

Tammisalo, K. \& Rotkirch. A. (forthcoming). Effects of information and communication technology on the quality of family relationships: A systematic review.

Tammisalo, K., Rotkirch, A., Alanko, L., Danielsbacka, M., Honkanen, J., Hämäläinen, M., \& Prusskij, C. (2020). Digitaalinen hyvinvointi perheissä: Suomi hyvin käytetyn ajan mallimaaksi [Digital well-being in families: Finland as a model country for well-spent time]. Valtioneuvoston selvitys- ja tutkimustoiminta 2020:43

Tanskanen, A. (2018). Sosiaalisen median aktiivikäyttö ja syntyvyys [Social media use and birth rate]. Retrieved from https://ajtanskanen.github.io/syntyvyys_some.html

Thompson, D. (2019). Workism Is Making Americans Miserable. For the college-educated elite, work has morphed into a religious identity—promising transcendence and community, but failing to deliver. Retrieved from The Atlantic website: https://www.theatlantic.com/ideas/archive/2019/02/religion-workism-makingamericans-miserable/583441/

Van Buuren, S. (2018). Flexible imputation of missing data. CRC press.

Vignoli, D., Bazzani, G., Guetto, R., Minello, A., \& Pirani, E. (2020a). Uncertainty and Narratives of the Future: A Theoretical Framework for Contemporary Fertility. In R. Schoen (Ed.), Analyzing Contemporary Fertility. The Springer Series on Demographic Methods and Population Analysis (pp. 25-47). https://doi.org/10.1007/978-3-03048519-1_3

Vignoli, D., Guetto, R., Bazzani, G., Pirani, E., \& Minello, A. (2020b). A reflection on economic uncertainty and fertility in Europe: The Narrative Framework. Genus, 76(1), 28. https://doi.org/10.1186/s41118-020-00094-3 
Westoff, C. F., \& Koffman, D. A. (2011). The association of television and radio with reproductive behavior. Population and Development Review, 37(4), 749-759. https://doi.org/10.1111/j.1728-4457.2011.00455.x 
Table 1. Sample characteristics.

\begin{tabular}{|c|c|c|c|}
\hline Variable, \% (n) & $\begin{array}{l}\text { Total sample } \\
(n=3468)\end{array}$ & $\begin{array}{l}\text { Childless } \\
(n=2002)\end{array}$ & $\begin{array}{l}\text { Parents } \\
(n=1466)\end{array}$ \\
\hline Age, Mean (SD) & $33.6(6.98)$ & $31.6(7.10)$ & $36.3(5.81)$ \\
\hline $20-29$ & $31.1(1080)$ & $42.1(863)$ & $14.8(85.2)$ \\
\hline $30-39$ & $42.1(1460)$ & $37.8(757)$ & $48.0(703)$ \\
\hline $40-44$ & $26.8(928)$ & $19.1(382)$ & $37.2(546)$ \\
\hline \multicolumn{4}{|l|}{ Gender } \\
\hline Male & $36.5(1265)$ & $36.4(729)$ & $36.6(536)$ \\
\hline Female & $63.5(2203)$ & $63.6(1273)$ & $63.4(930)$ \\
\hline \multicolumn{4}{|l|}{ Partnership status } \\
\hline Not married/ not cohabiting & $42.0(1456)$ & $60.5(1211)$ & $16.7(245)$ \\
\hline Cohabiting & $26.5(920)$ & $27.8(556)$ & $24.8(364)$ \\
\hline Married & $31.5(1092)$ & $11.7(235)$ & $58.5(857)$ \\
\hline Number of children, Mean (SD) & $0.72(0.97)$ & - & $1.71(0.73)$ \\
\hline 0 & $57.8(2002)$ & - & - \\
\hline 1 & $19.0(658)$ & - & $45.0(658)$ \\
\hline 2 & $16.5(570)$ & - & $38.9(570)$ \\
\hline $3+$ & $6.8(236)$ & - & $16.1(236)$ \\
\hline \multicolumn{4}{|l|}{ Education } \\
\hline Basic & $4.0(136)$ & $3.9(78)$ & $4.0(59)$ \\
\hline Secondary & $38.4(1320)$ & $40.7(815)$ & $35.2(515)$ \\
\hline Lower tertiary & $38.4(1320)$ & $36.8(737)$ & $40.5(593)$ \\
\hline Higher tertiary & $19.2(663)$ & $18.5(372)$ & $20.4(299)$ \\
\hline Income, Mean (SD) & $3.11(1.56)$ & $2.81(1.54)$ & $3.53(1.48)$ \\
\hline \multicolumn{4}{|l|}{ Employment } \\
\hline Employed & $67.7(2348)$ & $60.8(1217)$ & $77.2(1231)$ \\
\hline Unemployed & $10.3(358)$ & $12.7(255)$ & $7.0(103)$ \\
\hline Not working ${ }^{\text {a }}$ & $22.0(762)$ & $26.5(530)$ & $15.8(232)$ \\
\hline \multicolumn{4}{|l|}{ House ownership } \\
\hline Not owning a house & $49.3(1708)$ & $60.4(1210)$ & $34.0(498)$ \\
\hline Being a house owner & $50.7(1760)$ & $39.6(792)$ & $66.0(968)$ \\
\hline \multicolumn{4}{|l|}{ Region of residence } \\
\hline Metropolitan area & 30.5 (1059) & $33.2(665)$ & $26.9(394)$ \\
\hline Uusimaa and Southern Finland & $26.0(903)$ & $24.5(490)$ & $28.2(413)$ \\
\hline Western Finland & $25.4(879)$ & $25.0(501)$ & $25.8(378)$ \\
\hline Northern and Eastern Finland & $18.1(627)$ & $17.3(346)$ & $19.2(281)$ \\
\hline \multicolumn{4}{|l|}{ Social media use ${ }^{b}$} \\
\hline Never/rare/sometimes & $24.5(343)$ & $25.2(226)$ & $23.2(117)$ \\
\hline Often & $36.3(508)$ & $34.0(305)$ & $40.2(203)$ \\
\hline All the time/very often & $39.3(550)$ & $40.8(365)$ & $36.6(185)$ \\
\hline
\end{tabular}


Uncertain life situation factor, Median (interquartile range) ${ }^{\mathrm{c}}$

Lifestyle preferences factor,

Median (interquartile range) ${ }^{\mathrm{d}}$

Note. \% (n) are reported unless otherwise is specified.

${ }^{a}$ Being a student/on maternity or paternity leave/retired.

${ }^{\mathrm{b}}$ Social media use was reported only in 2018 survey $(\mathrm{n}=1401)$.

c Summary score; median (interquartile range) are reported, range 0-40.

${ }^{\mathrm{d}}$ Summary score; median (interquartile range) are reported, range 0-28. 
Table 2. Rotated factor loadings for all items $(n=3468)$.

\begin{tabular}{|c|c|c|c|c|}
\hline \# of item & Variable & $\begin{array}{l}\text { Factor } 1 \\
\text { 'Uncertain life } \\
\text { situation' }\end{array}$ & $\begin{array}{l}\text { Factor } 2 \\
\text { 'Lifestyle } \\
\text { preference' }\end{array}$ & $\begin{array}{l}\text { Factor } 3 \\
\text { 'Completed } \\
\text { fertility' }\end{array}$ \\
\hline 6 & My own or my family's financial situation prevents me & 0.75 & -0.03 & 0.00 \\
\hline 4 & My work situation is uncertain & 0.74 & 0.04 & -0.14 \\
\hline 5 & My spouse's work situation is uncertain & 0.67 & -0.14 & 0.18 \\
\hline 9 & Insufficient support from society & 0.66 & -0.11 & 0.14 \\
\hline 7 & My own or my spouse's unfinished studies & 0.65 & 0.06 & -0.10 \\
\hline 11 & The current apartment is too small & 0.57 & 0.12 & 0.01 \\
\hline 10 & It would be difficult to arrange childcare & 0.51 & 0.14 & 0.21 \\
\hline 3 & I want to advance in my profession or career & 0.49 & 0.36 & -0.07 \\
\hline 18 & $\begin{array}{l}\text { It would be difficult to combine work with the care of a small child } \\
\text { At the moment, I would not want to have a break in my work due to family }\end{array}$ & 0.43 & 0.29 & 0.13 \\
\hline 17 & leave & 0.34 & 0.27 & 0.17 \\
\hline 1 & I don't have a suitable partner & 0.27 & 0.15 & -0.12 \\
\hline 22 & I would have to give up my current lifestyle & 0.07 & 0.77 & -0.06 \\
\hline 15 & I want to do the other things that interest me & 0.13 & 0.75 & -0.09 \\
\hline 23 & I don’t like children & -0.06 & 0.66 & 0.07 \\
\hline 24 & I don't think I am suitable for parenting & 0.00 & 0.65 & 0.03 \\
\hline 25 & I don't want (any longer) to tie myself to small children & -0.16 & 0.56 & 0.33 \\
\hline 14 & I'm still too young, or I do not feel mature enough & 0.41 & 0.43 & -0.18 \\
\hline 16 & Children are not 'current/topical' in our relationship & 0.17 & 0.39 & 0.21 \\
\hline 27 & My spouse is too old & -0.09 & 0.04 & 0.78 \\
\hline 26 & I'm too old & -0.24 & 0.17 & 0.68 \\
\hline 21 & I already have the number of children I want & -0.09 & -0.02 & 0.61 \\
\hline
\end{tabular}


Note. The estimates highlighted in bold loaded high $(>0.30)$ on the factor of interest. 
Table 3. Mutually adjusted associations between socio-demographic characteristics and identified factors of self-reported reasons to postpone childbearing $(n=3468)$.

\begin{tabular}{|c|c|c|c|c|}
\hline \multirow[b]{2}{*}{ Predictors } & \multicolumn{2}{|c|}{$\begin{array}{c}\text { Uncertain life situation } \\
\text { factor }\end{array}$} & \multicolumn{2}{|c|}{$\begin{array}{c}\text { Lifestyle preferences } \\
\text { factor }\end{array}$} \\
\hline & IRR & $95 \% \mathrm{CI}$ & IRR & $95 \% \mathrm{CI}$ \\
\hline Age & 0.97 & $0.97,0.98$ & 0.99 & 0.99. 0.99 \\
\hline \multicolumn{5}{|l|}{ Gender } \\
\hline Male & 1.00 & & 1.00 & \\
\hline Female & 0.98 & $0.93,1.02$ & 1.06 & $1.01,1.11$ \\
\hline \multicolumn{5}{|l|}{ Number of children } \\
\hline 0 & 1.00 & & 1.00 & \\
\hline 1 & 1.15 & $1.08,1.22$ & 0.71 & $0.66,0.76$ \\
\hline 2 & 1.15 & $1.07,1.25$ & 0.75 & $0.69,0.82$ \\
\hline $3+$ & 1.14 & $1.04,1.25$ & 0.71 & $0.64,0.78$ \\
\hline \multicolumn{5}{|l|}{ Partnership status } \\
\hline Not married/ not cohabiting & 1.00 & & 1.00 & \\
\hline Cohabiting & 1.17 & $1.10,1.23$ & 1.06 & $1.01,1.14$ \\
\hline Married & 1.08 & $1.01,1.16$ & 1.03 & $0.96,1.11$ \\
\hline \multicolumn{5}{|l|}{ Education } \\
\hline Basic & 1.00 & & 1.00 & \\
\hline Secondary & 0.99 & $0.85,1.15$ & 0.94 & $0.80,1.09$ \\
\hline Lower tertiary & 1.04 & $0.90,1.22$ & 0.97 & $0.83,1.13$ \\
\hline Higher tertiary & 1.09 & $0.93,1.28$ & 0.98 & $0.83,1.15$ \\
\hline Income & 0.97 & $0.95,0.99$ & 1.00 & $0.97,1.02$ \\
\hline \multicolumn{5}{|l|}{ Employment } \\
\hline Employed & 1.00 & & 1.00 & \\
\hline Unemployed & 0.99 & $0.91,1.08$ & 0.95 & $0.87,1.03$ \\
\hline Not working* & 1.00 & $0.93,1.07$ & 1.00 & $0.93,1.08$ \\
\hline \multicolumn{5}{|l|}{ House ownership } \\
\hline Not owning a house & 1.00 & & 1.00 & \\
\hline Being a house owner & 0.96 & $0.91,1.02$ & 0.98 & $0.93,1.04$ \\
\hline \multicolumn{5}{|l|}{ Region of residence } \\
\hline Metropolitan area & 1.00 & & 1.00 & \\
\hline Uusimaa and Southern Finland & 0.92 & $0.86,0.98$ & 0.97 & $0.91,1.04$ \\
\hline Western Finland & 0.94 & $0.88,1.00$ & 0.96 & $0.90,1.02$ \\
\hline Northern and Eastern Finland & 0.92 & $0.86,0.99$ & 1.01 & $0.94,1.08$ \\
\hline
\end{tabular}




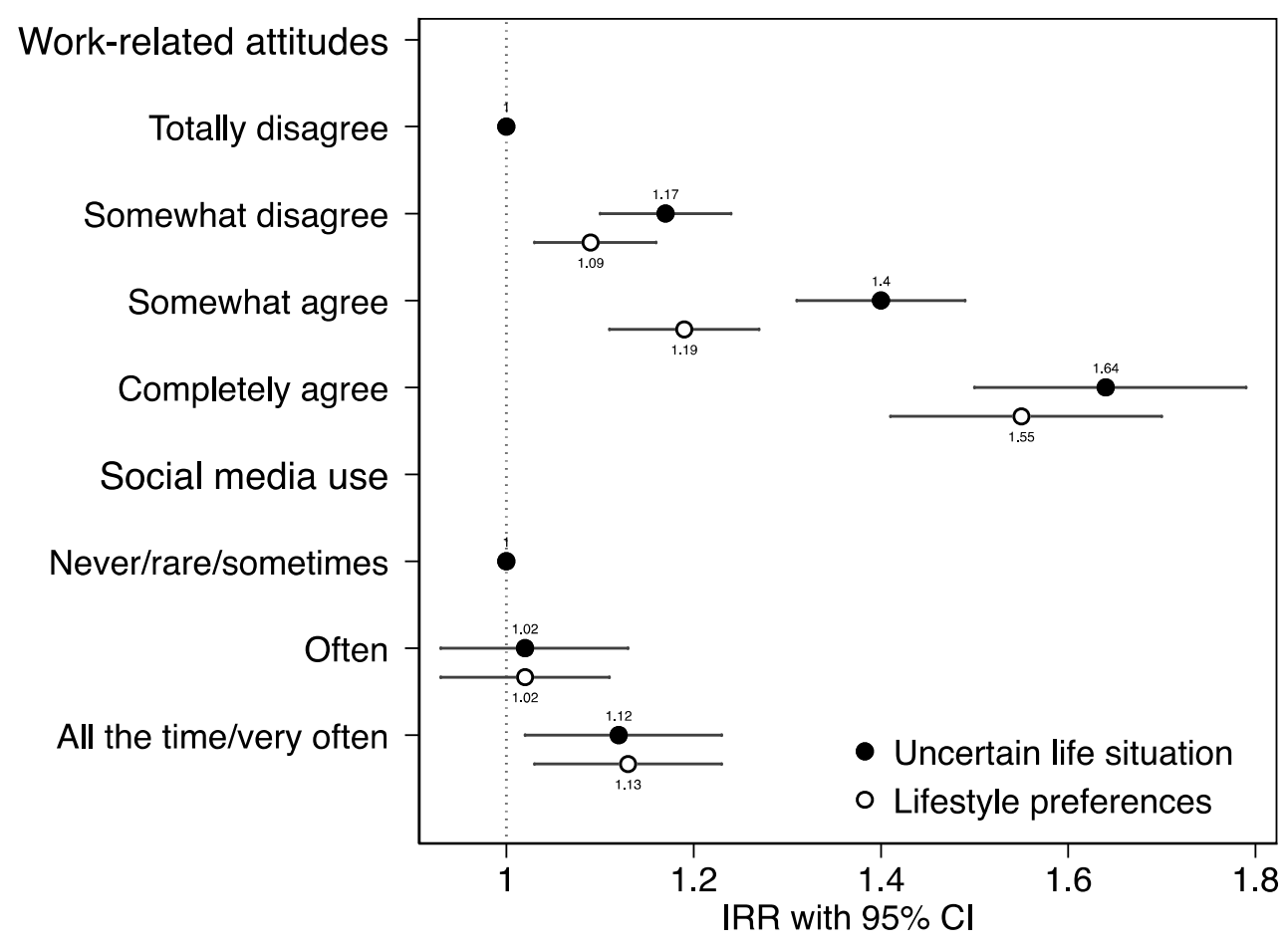

Figure 1. Associations between social media use and work-related attitudes with the identified factors of self-reported reasons to postpone or not to have (more) children in the total sample.

Note. $\mathrm{IRR}=$ incidence rate ratio, $\mathrm{CI}=$ confidence interval. Work-related attitudes were measured with the question "Most of my life goals are related to work". Social media use and work-related attitudes were analyzed in separate models. Analyses with work-related attitudes were conducted in the full sample ( $\mathrm{n}=$ 3468), whereas the analyses with social media use were conducted in the restricted sample ( $\mathrm{n}=1401)$, because social media use was reported only in 2018 survey. All analyses were adjusted for age, gender, partnership status, number of children, education, income, employment, house ownership, region of residence, and the survey year. 

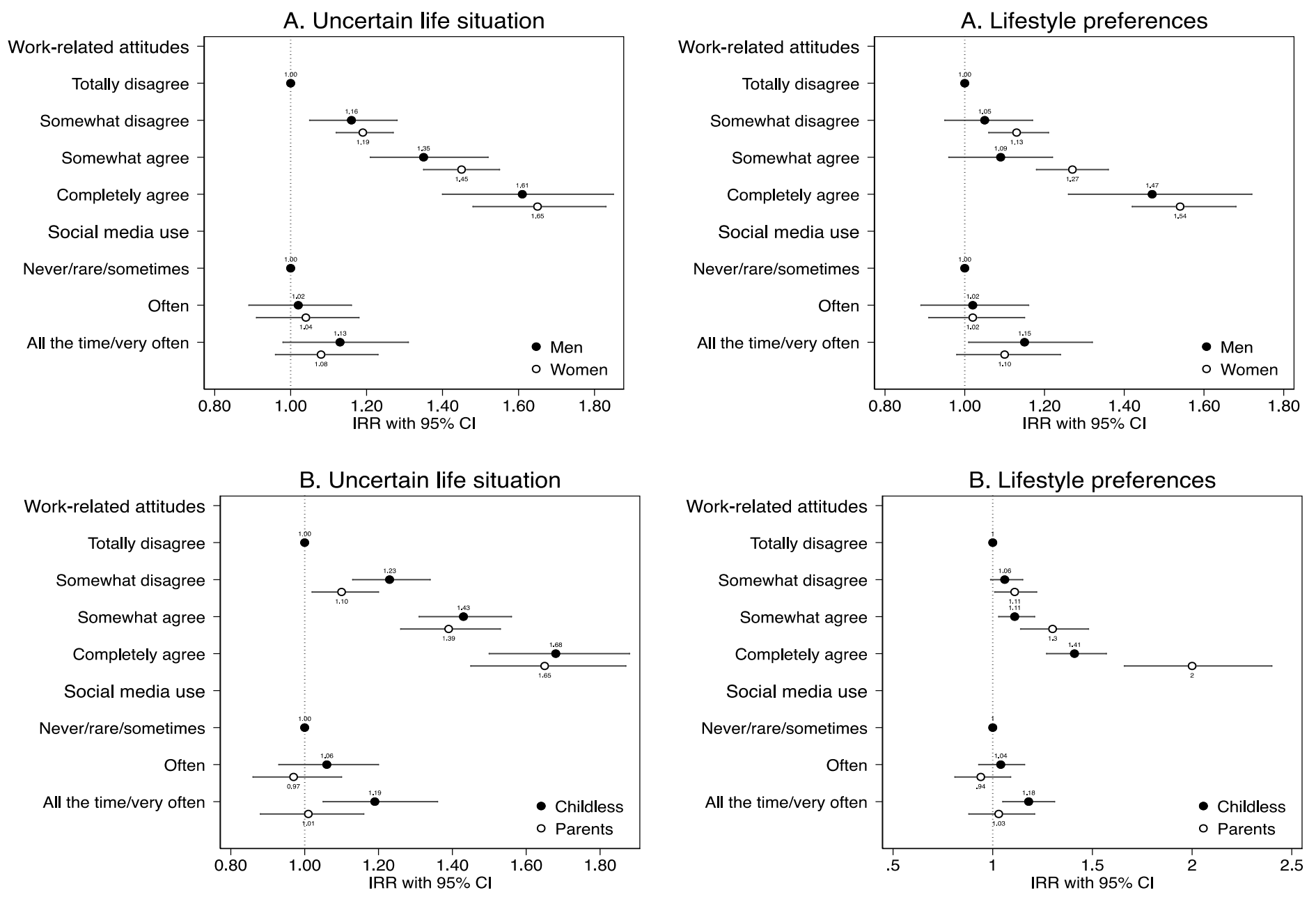

Figure 2. Associations between social media use and work-related attitudes with the identified factors of self-reported reasons to postpone or not to have (more) children among men and women (panel A) and among childless and parents (panel B). 
Note. $\mathrm{IRR}=$ incidence rate ratio, $\mathrm{CI}=$ confidence interval.

Work-related attitudes were measured with the question "Most of my life goals are related to work". Social media use and work-related attitudes were analyzed in separate models. Analyses with work-related attitudes were conducted in the full sample $(\mathrm{n}=3468)$, whereas the analyses with social media use were conducted in the restricted sample $(n=1401)$, because social media use was reported only in 2018 survey. All analyses were adjusted for age, partnership status, education, income, employment, house ownership, region of residence, and the survey year. 


\section{SUPPLEMENTARY MATERIALS}

\section{Reasons to postpone childbearing during fertility decline in Finland}

Supplementary Table 1. List of perceived reasons to postpone or not to have (more) children.

Finnish Family Barometer Survey 2015: 'Many different things can affect whether having a child does not seem timely or no longer relevant. Please tell us how important each of the following thing is for your decision.' (response scale: 1 = very important, 2 = somewhat important, 3 = not very important, 4 = not important at all, 5 = can't say / doesn't apply to me)

Finnish Family Barometer Survey 2018: 'If you are not planning to have a child, or if having a child does not seem timely, to what extent the following things affect this?' (response scale: $1=$ affects a lot, $2=$ has some effect, $3=$ has little effect, $4=$ does not affect at all, and $5=$ can't say / doesn't apply to me)

\section{I don't have a suitable partner}

2. My spouse does not want children (not yet/more)

3. I want to advance in my profession or career

4. My work situation is uncertain

5. My spouse's work situation is uncertain

6. My own or my family's financial situation prevents me

7. My own or my spouse's unfinished studies

8. My own or my spouse's health state prevents

9. Insufficient support from society

10. It would be difficult to arrange childcare

11. The current apartment is too small

12. Problems in our relationship

13. The youngest child is still too young

14. I'm still too young, or I don't feel mature enough

15. I want to do other things that interest me

16. Children are not 'current/topical' in our relationship

17. At the moment, I would not want to have a break in my work due to family leave

18. It would be difficult to combine work with the care of a small child

19. I/we cannot have (more) children of my/our own

20. The experience of previous pregnancy complications / fear of giving birth

21. I already have the number of children I want

22. I would have to give up my current lifestyle

23. I don't like children

24. I don't think I'm suitable for parenting

25 . I don't want (any longer) to tie myself to small children

26. I'm too old

27. My spouse is too old 
Supplementary Table 2. Distribution (\%) of responses for perceived reasons to postpone childbearing.

\begin{tabular}{|c|c|c|c|c|c|}
\hline List of perceived reasons to postpone childbearing & $\begin{array}{l}0=\text { can't say } \\
\text { or doesn't } \\
\text { apply to me }\end{array}$ & $\begin{array}{l}1=\text { not important } \\
\text { at all/does not } \\
\text { affect at all }\end{array}$ & $\begin{array}{l}2=\text { not very } \\
\text { important/has } \\
\text { little effect }\end{array}$ & $\begin{array}{l}3=\text { somewhat } \\
\text { important/has } \\
\text { some effect }\end{array}$ & $\begin{array}{l}4=\text { very } \\
\text { important/affects } \\
\text { a lot }\end{array}$ \\
\hline 1. I don't have a suitable partner & 37.6 & 21.3 & 5.8 & 8.7 & 26.6 \\
\hline 2. My spouse does not want children (not yet/more) & 43.8 & 14.5 & 7.3 & 13.1 & 21.3 \\
\hline 3. I want to advance in my profession or career & 22.4 & 24.7 & 18.9 & 21.1 & 13.0 \\
\hline 4. My work situation is uncertain & 26.5 & 26.5 & 15.0 & 17.4 & 14.5 \\
\hline 5. My spouse's work situation is uncertain & 41.4 & 25.4 & 11.7 & 13.6 & 7.9 \\
\hline \multicolumn{6}{|l|}{ 6. My own or my family's financial situation prevents } \\
\hline me & 25.9 & 24.2 & 14.9 & 20.3 & 14.8 \\
\hline 7. My own or my spouse's unfinished studies & 41.2 & 26.3 & 8.9 & 11.9 & 11.6 \\
\hline 8. My own or my spouse's health state prevents & 41.2 & 28.8 & 8.6 & 10.5 & 10.9 \\
\hline 9. Insufficient support from society & 27.1 & 30.5 & 20.7 & 14.9 & 6.9 \\
\hline 10. It would be difficult to arrange childcare & 26.7 & 27.0 & 20.7 & 17.9 & 7.7 \\
\hline 11. The current apartment is too small & 26.2 & 29.2 & 15.8 & 26.9 & 11.9 \\
\hline 12. Problems in our relationship & 49.9 & 24.4 & 8.7 & 9.3 & 7.7 \\
\hline 13. The youngest child is still too young & 55.9 & 23.4 & 7.1 & 7.7 & 5.9 \\
\hline 14. I'm still too young, or I don't feel mature enough & 40.9 & 30.2 & 8.2 & 9.3 & 11.5 \\
\hline 15. I want to do the other things that interest me & 20.8 & 17.5 & 13.3 & 22.2 & 26.2 \\
\hline 16. Children are not 'current/topical' in our relationship & 43.7 & 16.9 & 7.4 & 12.4 & 19.7 \\
\hline $\begin{array}{l}\text { 17. At the moment, I would not want to have a break in } \\
\text { my work due to family leave }\end{array}$ & 35.7 & 32.6 & 11.7 & 11.3 & 8.8 \\
\hline 18. It would be difficult to combine work with the care & & & & & \\
\hline of a small child & 29.2 & 25.1 & 16.6 & 18.2 & 10.9 \\
\hline 19. I/we cannot have (more) children of my / our own & 61.2 & 20.9 & 4.8 & 5.4 & 7.8 \\
\hline 20. The experience of previous pregnancy complications & & & & & \\
\hline / fear of giving birth & 51.5 & 23.7 & 9.3 & 10.4 & 5.1 \\
\hline 21. I already have the number of children I want & 47.2 & 13.2 & 5.6 & 9.0 & 25.1 \\
\hline 22. I would have to give up my current lifestyle & 23.4 & 21.9 & 14.9 & 20.0 & 19.8 \\
\hline 23. I don't like children & 38.7 & 31.9 & 9.5 & 9.3 & 10.7 \\
\hline 24. I don't think I'm suitable for parenting & 36.0 & 30.1 & 11.8 & 11.8 & 10.4 \\
\hline
\end{tabular}


25. I don't want (any longer) to tie myself to small children

11.5

12.5

9.8
17.0

14.6

9.0
25.4

12.8

7.4 
Supplementary Table 3. Means of perceived reasons to postpone or not to have (more) children in 2015 and 2018.

\begin{tabular}{|c|c|c|c|}
\hline List of perceived reasons to postpone or renounce childbearing & $\begin{array}{l}2015 \\
(n=2060)\end{array}$ & $\begin{array}{l}2018 \\
(n=1408)\end{array}$ & p-value* \\
\hline 1. I don't have a suitable partner & 1.72 & 1.56 & 0.005 \\
\hline 2. My spouse does not want children (not yet/more) & 1.77 & 1.20 & $<0.001$ \\
\hline 3. I want to advance in my profession or career & 1.85 & 1.66 & $<0.001$ \\
\hline 4. My work situation is uncertain & 1.68 & 1.65 & 0.474 \\
\hline 5. My spouse's work situation is uncertain & 1.30 & 1.09 & $<0.001$ \\
\hline 6. My own or my family's financial situation prevents me & 1.78 & 1.67 & 0.022 \\
\hline 7. My own or my spouse's unfinished studies & 1.28 & 1.24 & 0.399 \\
\hline 8. My own or my spouse's health state prevents & 1.21 & 1.22 & 0.892 \\
\hline 9. Insufficient support from society & 1.45 & 1.43 & 0.673 \\
\hline 10. It would be difficult to arrange childcare & 1.56 & 1.48 & 0.083 \\
\hline 11. The current apartment is too small & 1.56 & 1.63 & 0.121 \\
\hline 12. Problems in our relationship & 1.00 & 1.01 & 0.917 \\
\hline 13. The youngest child is still too young & 0.90 & 0.77 & 0.002 \\
\hline 14. I'm still too young, or I don't feel mature enough & 1.18 & 1.24 & 0.213 \\
\hline 15. I want to do the other things that interest me & 2.12 & 2.21 & 0.096 \\
\hline 16. Children are not 'current/topical' in our relationship & 1.47 & 1.48 & 0.912 \\
\hline $\begin{array}{l}\text { 17. At the moment, I would not want to have a break in my } \\
\text { work due to family leave }\end{array}$ & 1.28 & 1.20 & 0.061 \\
\hline $\begin{array}{l}\text { 18. It would be difficult to combine work with the care of a } \\
\text { small child }\end{array}$ & 1.56 & 1.57 & 0.763 \\
\hline 19. I/we cannot have (more) children of my / our own & 0.74 & 0.83 & 0.354 \\
\hline $\begin{array}{l}\text { 20. The experience of previous pregnancy complications / fear } \\
\text { of giving birth }\end{array}$ & 0.95 & 0.93 & 0.717 \\
\hline 21. I already have the number of children I want & 1.66 & 1.30 & $<0.001$ \\
\hline 22. I would have to give up my current lifestyle & 1.83 & 2.02 & $<0.001$ \\
\hline 23. I don't like children & 1.15 & 1.31 & $<0.001$ \\
\hline 24. I don't think I'm suitable for parenting & 1.24 & 1.40 & $<0.001$ \\
\hline 25. I don't want (any longer) to tie myself to small children & 2.01 & 1.84 & 0.001 \\
\hline 26. I'm too old & 1.44 & 1.53 & 0.067 \\
\hline 27. My spouse is too old & 1.01 & 1.05 & 0.328 \\
\hline
\end{tabular}

Note. P-values are from the independent samples t-tests. 
Supplementary Table 4. Rotated factor loadings for all items when treating the response ' $0=$ can't say or doesn't apply to me' as missing $(\mathrm{n}=$ 660).

\begin{tabular}{|c|c|c|c|c|}
\hline \# of item & Variable & Factor 1 & Factor 2 & Factor 3 \\
\hline 6 & My own or my family's financial situation prevents me & 0.83 & -0.07 & -0.04 \\
\hline 9 & Insufficient support from society & $\mathbf{0 . 8 0}$ & -0.14 & -0.07 \\
\hline 4 & My work situation is uncertain & 0.74 & 0.03 & -0.05 \\
\hline 11 & The current apartment is too small & 0.73 & -0.02 & -0.10 \\
\hline 5 & My spouse's work situation is uncertain & 0.73 & 0.00 & 0.06 \\
\hline 10 & It would be difficult to arrange childcare & 0.71 & 0.09 & -0.09 \\
\hline 7 & My own or my spouse's unfinished studies & 0.65 & 0.12 & -0.01 \\
\hline 13 & The youngest child is still too young & 0.60 & -0.11 & 0.10 \\
\hline 18 & It would be difficult to combine work with the care of a small child & 0.57 & 0.29 & -0.06 \\
\hline 8 & My own or my spouse's health state prevents & 0.51 & -0.06 & 0.39 \\
\hline 17 & At the moment, I would not want to have a break in my work due to family leave & 0.49 & 0.33 & 0.04 \\
\hline 12 & Problems in our relationship & 0.48 & -0.03 & 0.42 \\
\hline 1 & I don't have a suitable partner & 0.46 & -0.03 & 0.37 \\
\hline 20 & The experience of previous pregnancy complications / fear of giving birth & 0.45 & 0.05 & 0.34 \\
\hline 14 & I'm still too young, or I do not feel mature enough & 0.42 & 0.30 & 0.18 \\
\hline 22 & I would have to give up my current lifestyle & -0.07 & 0.85 & -0.10 \\
\hline 15 & I want to do the other things that interest me & 0.02 & 0.81 & -0.11 \\
\hline 25 & I don't want (any longer) to tie myself to small children & -0.19 & 0.71 & 0.20 \\
\hline 24 & I don't think I am suitable for parenting & 0.09 & 0.57 & 0.17 \\
\hline 23 & I don't like children & 0.04 & 0.56 & 0.18 \\
\hline 3 & I want to advance in my profession or career & 0.45 & 0.46 & -0.10 \\
\hline 16 & Children are not 'current/topical' in our relationship & 0.13 & 0.44 & 0.18 \\
\hline 27 & My spouse is too old & -0.05 & -0.02 & $\mathbf{0 . 8 3}$ \\
\hline 26 & I'm too old & -0.21 & 0.07 & 0.82 \\
\hline 19 & I/we cannot have (more) children of my/our own & 0.31 & -0.04 & 0.50 \\
\hline 2 & My spouse does not want children (not yet/more) & 0.23 & 0.05 & 0.42 \\
\hline 21 & I already have the number of children I want & -0.09 & 0.18 & 0.41 \\
\hline
\end{tabular}


Supplementary Table 5. Rotated factor loadings for all items among those participants who postponing childbearing $(\mathrm{n}=1268)$.

\begin{tabular}{|c|c|c|c|c|}
\hline \# of item & Variable & $\begin{array}{l}\text { Factor 1 } \\
\text { 'Uncertain life } \\
\text { situation' }\end{array}$ & $\begin{array}{l}\text { Factor } 2 \\
\text { 'Lifestyle } \\
\text { preferences' }\end{array}$ & $\begin{array}{l}\text { Factor } 3 \\
\text { 'Completed } \\
\text { fertility' }\end{array}$ \\
\hline 6 & My own or my family's financial situation prevents me & 0.66 & 0.04 & 0.01 \\
\hline 5 & My spouse's work situation is uncertain & 0.65 & -0.12 & 0.10 \\
\hline 9 & Insufficient support from society & 0.62 & -0.12 & 0.12 \\
\hline 4 & My work situation is uncertain & 0.57 & 0.14 & -0.06 \\
\hline 10 & It would be difficult to arrange childcare & 0.56 & 0.07 & 0.13 \\
\hline 18 & It would be difficult to combine work with the care of a small child & 0.50 & 0.19 & 0.03 \\
\hline 3 & I want to advance in my profession or career & 0.49 & 0.43 & -0.15 \\
\hline 7 & My own or my spouse's unfinished studies & 0.48 & 0.24 & -0.11 \\
\hline 11 & The current apartment is too small & 0.46 & 0.20 & -0.01 \\
\hline 17 & At the moment, I would not want to have a break in my work due to family leave & 0.39 & 0.15 & 0.10 \\
\hline 15 & I want to do the other things that interest me & 0.19 & 0.77 & -0.13 \\
\hline 14 & I'm still too young, or I do not feel mature enough & 0.08 & 0.75 & -0.01 \\
\hline 22 & I would have to give up my current lifestyle & 0.11 & 0.74 & -0.06 \\
\hline 24 & I don't think I am suitable for parenting & -0.10 & 0.59 & 0.35 \\
\hline 23 & I don't like children & -0.05 & 0.55 & 0.35 \\
\hline 16 & Children are not 'current/topical' in our relationship & 0.19 & 0.51 & 0.11 \\
\hline 25 & I don't want (any longer) to tie myself to small children & 0.11 & 0.46 & 0.26 \\
\hline 13 & The youngest child is still too young & 0.39 & -0.45 & 0.39 \\
\hline 1 & I don't have a suitable partner & -0.15 & 0.29 & 0.26 \\
\hline 27 & My spouse is too old & -0.05 & 0.07 & 0.79 \\
\hline 26 & I'm too old & -0.17 & 0.11 & 0.73 \\
\hline 19 & $\mathrm{I} /$ we cannot have more children of my / our own & -0.10 & 0.09 & 0.69 \\
\hline 21 & I already have the number of children I want & 0.23 & -0.10 & 0.59 \\
\hline 12 & Problems in our relationship & 0.19 & 0.06 & 0.52 \\
\hline 8 & My own or my spouse's health state prevents & 0.14 & 0.11 & 0.52 \\
\hline 20 & The experience of previous pregnancy complications / fear of giving birth & 0.18 & 0.00 & 0.46 \\
\hline 2 & My spouse does not want children (not yet/more) & 0.31 & 0.02 & 0.36 \\
\hline
\end{tabular}


Supplementary Table 6. Rotated factor loadings for all items among those participants who renounce childbearing $(\mathrm{n}=1734)$.

\begin{tabular}{|c|c|c|c|c|c|}
\hline \# of item & Variable & $\begin{array}{l}\text { Factor 1 } \\
\text { 'Uncertain } \\
\text { life situation' }\end{array}$ & $\begin{array}{l}\text { Factor } 2 \\
\text { 'Lifestyle } \\
\text { preferences' }\end{array}$ & $\begin{array}{l}\text { Factor } 3 \\
\text { 'Completed } \\
\text { fertility' }\end{array}$ & $\begin{array}{l}\text { Factor } 4 \\
\text { 'Not ready } \\
\text { for parenting' }\end{array}$ \\
\hline 6 & My own or my family's financial situation prevents me & 0.76 & 0.06 & -0.05 & -0.03 \\
\hline 4 & My work situation is uncertain & 0.76 & 0.04 & -0.14 & 0.10 \\
\hline 9 & Insufficient support from society & 0.69 & 0.02 & 0.05 & -0.07 \\
\hline 7 & My own or my spouse's unfinished studies & 0.64 & 0.00 & 0.01 & 0.12 \\
\hline 5 & My spouse's work situation is uncertain & 0.58 & 0.03 & 0.23 & -0.03 \\
\hline 11 & The current apartment is too small & 0.56 & 0.17 & -0.01 & 0.02 \\
\hline 1 & I don't have a suitable partner & 0.49 & -0.09 & -0.14 & 0.26 \\
\hline 10 & It would be difficult to arrange childcare & 0.47 & 0.41 & 0.04 & -0.14 \\
\hline 13 & The youngest child is still too young & 0.44 & -0.06 & 0.32 & -0.15 \\
\hline 15 & I want to do the other things that interest me & -0.04 & 0.68 & -0.07 & 0.32 \\
\hline 22 & I would have to give up my current lifestyle & -0.06 & 0.66 & -0.04 & 0.38 \\
\hline 18 & It would be difficult to combine work with the care of a small child & 0.27 & 0.61 & 0.03 & -0.08 \\
\hline 25 & $\begin{array}{l}\text { I don't want (any longer) to tie myself to small children } \\
\text { At the moment, I would not want to have a break in my work due to family }\end{array}$ & -0.16 & 0.58 & 0.14 & 0.08 \\
\hline 17 & leave & 0.21 & 0.56 & 0.07 & -0.04 \\
\hline 3 & I want to advance in my profession or career & 0.30 & 0.55 & -0.08 & 0.01 \\
\hline 27 & My spouse is too old & -0.12 & 0.04 & 0.78 & -0.06 \\
\hline 26 & I'm too old & -0.16 & 0.10 & 0.62 & 0.01 \\
\hline 2 & My spouse does not want children (not yet/more) & 0.01 & 0.18 & 0.52 & -0.14 \\
\hline 19 & I/we cannot have (more) children of my / our own & 0.14 & -0.21 & 0.49 & 0.17 \\
\hline 12 & Problems in our relationship & 0.38 & -0.02 & 0.45 & 0.10 \\
\hline 20 & The experience of previous pregnancy complications / fear of giving birth & 0.27 & 0.03 & 0.42 & 0.03 \\
\hline 8 & My own or my spouse's health state prevents & 0.37 & -0.19 & 0.39 & 0.23 \\
\hline 16 & Children are not 'current/topical' in our relationship & -0.01 & 0.29 & 0.34 & 0.19 \\
\hline 24 & I don't think I am suitable for parenting & 0.04 & 0.18 & 0.05 & 0.68 \\
\hline 23 & I don't like children & -0.03 & 0.26 & 0.05 & 0.63 \\
\hline 14 & I'm still too young, or I do not feel mature enough & 0.40 & 0.05 & 0.00 & 0.43 \\
\hline 21 & I already have the number of children I want & -0.02 & 0.18 & 0.34 & -0.39 \\
\hline
\end{tabular}


Supplementary Table 7. Mutually adjusted associations between socio-demographic characteristics and identified factors of perceived reasons to postpone childbearing separately among childless people and parents.

\begin{tabular}{|c|c|c|c|c|c|c|c|c|}
\hline & \multicolumn{4}{|c|}{ Uncertain life situation factor } & \multicolumn{4}{|c|}{ Lifestyle preferences factor } \\
\hline & \multicolumn{2}{|c|}{ Childless $(n=2002)$} & \multicolumn{2}{|c|}{ Parents $(n=1464)$} & \multicolumn{2}{|c|}{ Childless $(n=2002)$} & \multicolumn{2}{|c|}{ Parents $(n=1464)$} \\
\hline & IRR & $95 \% \mathrm{CI}$ & IRR & $95 \% \mathrm{CI}$ & IRR & $95 \% \mathrm{CI}$ & IRR & $95 \% \mathrm{CI}$ \\
\hline Age & 0.97 & $0.97,0.98$ & 0.98 & $0.97,0.98$ & 0.98 & $0.98,0.99$ & 1.00 & $1.00,1.01$ \\
\hline \multicolumn{9}{|l|}{ Gender } \\
\hline Male & 1.00 & & 1.00 & & 1.00 & & 1.00 & \\
\hline Female & 1.01 & $0.95,1.07$ & 0.91 & $0.85,0.98$ & 1.12 & 1.06, 1.19 & 0.94 & $0.87,1.03$ \\
\hline \multicolumn{9}{|l|}{ Partnership status } \\
\hline Not married/ not cohabiting & 1.00 & & 1.00 & & 1.00 & & 1.00 & \\
\hline Cohabiting & 1.19 & $1.12,1.28$ & 1.00 & $0.90,1.12$ & 1.11 & $1.04,1.19$ & 0.90 & $0.79,1.02$ \\
\hline Married & 1.18 & $1.07,1.31$ & 0.93 & $0.84,1.04$ & 1.18 & $1.07,1.30$ & $\mathbf{0 . 8 3}$ & $0.74,0.93$ \\
\hline \multicolumn{9}{|l|}{ Education } \\
\hline Basic & 1.00 & & 1.00 & & 1.00 & & 1.00 & \\
\hline Secondary & 1.05 & $0.82,1.34$ & 0.93 & $0.80,1.08$ & 0.95 & $0.78,1.17$ & 0.87 & $0.67,1.11$ \\
\hline Lower tertiary & 1.13 & $0.88,1.45$ & 0.94 & $0.81,1.09$ & 1.02 & $0.83,1.26$ & 0.86 & $0.67,1.09$ \\
\hline Higher tertiary & 1.15 & $0.89,1.49$ & 1.03 & $0.87,1.22$ & 0.99 & $0.80,1.23$ & 0.95 & $0.74,1.23$ \\
\hline Income & 0.97 & $0.93,1.00$ & 0.97 & $0.94,1.01$ & 0.99 & $0.96,1.02$ & 1.00 & $0.96,1.04$ \\
\hline \multicolumn{9}{|l|}{ Employment } \\
\hline Employed & 1.00 & & 1.00 & & 1.00 & & 1.00 & \\
\hline Unemployed & 1.00 & $0.89,1.13$ & 0.96 & $0.84,1.11$ & 1.01 & $0.91,1.13$ & 0.81 & $0.67,0.96$ \\
\hline Not working* & 0.98 & $0.90,1.08$ & 1.04 & $0.94,1.14$ & 1.02 & $0.93,1.11$ & 0.95 & $0.83,1.09$ \\
\hline \multicolumn{9}{|l|}{ House ownership } \\
\hline Not owning a house & 1.00 & & 1.00 & & 1.00 & & 1.00 & \\
\hline Being a house owner & 0.97 & $0.90,1.04$ & 1.00 & $0.92,1.08$ & 1.01 & $0.93,1.08$ & 0.99 & $0.90,1.09$ \\
\hline
\end{tabular}


Region of residence

Metropolitan area

1.00

Uusimaa and Southern Finland

$\mathbf{0 . 9 0}$

1.00

1.00

1.00

$0.88,1.04$

1.00

Western Finland

0.93

0.82, 0.98

$0.86,1.02$

0.96

$0.88,1.04$

0.99

$0.90,1.09$

Northern and Eastern Finland

$0.89 \quad 0.81,0.98$

0.94

$0.86,1.03$

$0.88,1.04$

0.94

$0.85,1.05$

Note. IRR = incidence rate ratio, $\mathrm{CI}=$ confidence interval

*Being a student/ on maternity or paternity leave

All analyses are adjusted for the survey year. 
Supplementary Table 8. Mutually adjusted associations between socio-demographic characteristics and identified factors of perceived reasons to postpone childbearing separately among men and women.

\begin{tabular}{|c|c|c|c|c|c|c|c|c|}
\hline & \multicolumn{4}{|c|}{ Uncertain life situation factor } & \multicolumn{4}{|c|}{$\begin{array}{c}\text { Lifestyle preferences factor } \\
\end{array}$} \\
\hline & \multicolumn{2}{|c|}{$\operatorname{Men}(n=1265)$} & \multicolumn{2}{|c|}{ Women $(n=2201)$} & \multicolumn{2}{|c|}{$\operatorname{Men}(n=1265)$} & \multicolumn{2}{|c|}{ Women $(n=2201)$} \\
\hline & IRR & $95 \% \mathrm{CI}$ & IRR & $95 \% \mathrm{CI}$ & IRR & $95 \% \mathrm{CI}$ & IRR & $95 \% \mathrm{CI}$ \\
\hline Age & 0.98 & $0.97,0.98$ & 0.97 & $0.97,0.98$ & 0.99 & $0.98,0.99$ & 0.99 & $0.99,1.00$ \\
\hline \multicolumn{9}{|l|}{ Number of children } \\
\hline 0 & 1.00 & & 1.00 & & 1.00 & & 1.00 & \\
\hline 1 & 1.13 & $1.01,1.26$ & 1.15 & $1.07,1.23$ & 0.76 & $0.67,0.86$ & 0.64 & $0.59,0.70$ \\
\hline 2 & 1.18 & $1.03,1.34$ & 1.12 & $1.03,1.22$ & $\mathbf{0 . 8 3}$ & $0.72,0.95$ & 0.67 & $0.62,0.73$ \\
\hline $3+$ & 1.07 & $0.92,1.24$ & 1.25 & $1.10,1.41$ & 0.75 & $0.64,0.89$ & 0.67 & $0.60,0.76$ \\
\hline \multicolumn{9}{|l|}{ Partnership status } \\
\hline Not married/ not cohabiting & 1.00 & & 1.00 & & 1.00 & & 1.00 & \\
\hline Cohabiting & 1.22 & $1.10,1.35$ & 1.12 & $1.06,1.19$ & 1.10 & $0.99,1.22$ & 1.04 & $0.98,1.10$ \\
\hline Married & 1.20 & $1.07,1.34$ & 0.98 & $1.01,1.13$ & 1.07 & $0.96,1.21$ & 0.98 & $0.91,1.06$ \\
\hline \multicolumn{9}{|l|}{ Education } \\
\hline Basic & 1.00 & & 1.00 & & 1.00 & & 1.00 & \\
\hline Secondary & 0.90 & $0.74,1.09$ & 1.23 & $1.04,1.45$ & 0.83 & $0.69,1.01$ & 1.21 & $1.01,1.45$ \\
\hline Lower tertiary & 0.94 & $0.77,1.15$ & 1.33 & $1.12,1.57$ & 0.86 & $0.71,1.05$ & 1.27 & $1.05,1.53$ \\
\hline Higher tertiary & 0.96 & $0.77,1.19$ & 1.43 & $1.20,1.71$ & 0.87 & $0.70,1.07$ & 1.29 & $1.07,1.57$ \\
\hline Income & 0.95 & $0.92,0.98$ & 0.99 & $0.96,1.02$ & 0.98 & $0.94,1.01$ & 1.01 & $0.98,1.04$ \\
\hline \multicolumn{9}{|l|}{ Employment } \\
\hline Employed & 1.00 & & 1.00 & & 1.00 & & 1.00 & \\
\hline Unemployed & 0.96 & $0.83,1.11$ & 1.03 & $0.93,1.13$ & 0.87 & $0.75,1.02$ & 1.03 & $0.94,1.13$ \\
\hline Not working* & 0.95 & $0.83,1.07$ & 1.06 & $0.99,1.14$ & 0.96 & $0.85,1.10$ & 1.05 & $0.97,1.13$ \\
\hline \multicolumn{9}{|l|}{ House ownership } \\
\hline Not owning a house & 1.00 & & 1.00 & & 1.00 & & 1.00 & \\
\hline Being a house owner & 1.00 & $0.92,1.10$ & 0.93 & $0.88,0.99$ & 1.03 & $0.94,1.13$ & 0.94 & $0.89,1.00$ \\
\hline \multicolumn{9}{|l|}{ Region of residence } \\
\hline Metropolitan area & 1.00 & & 1.00 & & 1.00 & & 1.00 & \\
\hline
\end{tabular}




\begin{tabular}{lllllllll} 
Uusimaa and Southern Finland & 0.90 & $0.81,1.00$ & 0.94 & $0.88,1.01$ & 0.98 & $0.88,1.081$ & 0.98 & $0.92,1.04$ \\
Western Finland & 0.95 & $0.85,1.06$ & $\mathbf{0 . 9 3}$ & $\mathbf{0 . 8 7 , 0 . 9 9}$ & 0.96 & $0.86,1.08$ & 0.94 & $0.88,1.01$ \\
Northern and Eastern Finland & 0.93 & $0.83,1.04$ & $\mathbf{0 . 9 1}$ & $\mathbf{0 . 8 5 , 0 . 9 9}$ & 1.00 & $0.89,1.12$ & 1.03 & $0.95,1.11$ \\
\hline
\end{tabular}

Note. IRR = incidence rate ratio, CI = confidence interval. All analyses are adjusted for the survey year. *Being a student/ on maternity or paternity leave. 


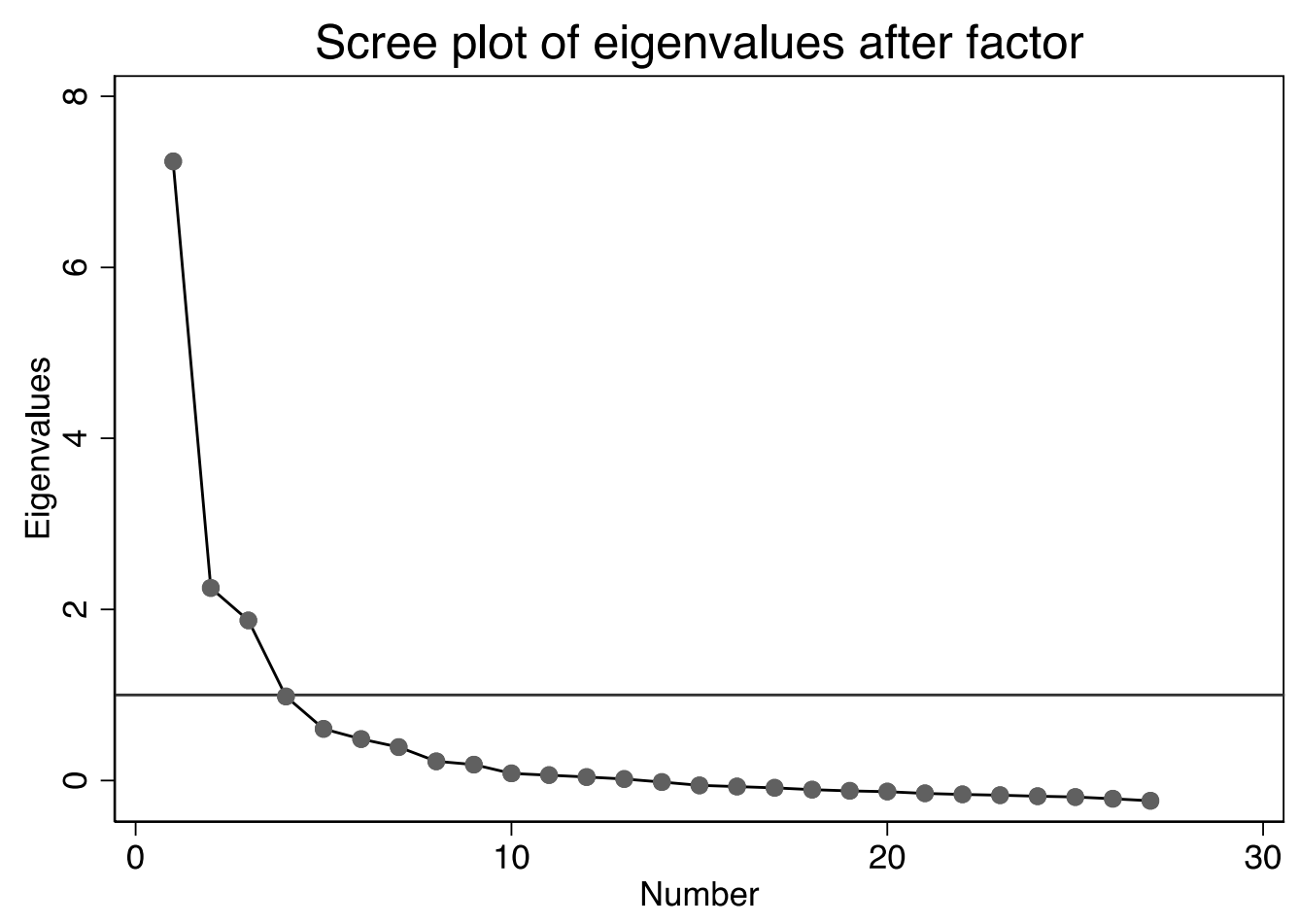

Supplementary Figure 1. Scree plots for the eigenvalues obtained from the exploratory factor analysis. 